\title{
Innovation by proxy - clusters as ecosystems facilitating open innovation
}

\section{Marita McPhillips ${ }^{1}$}

\begin{abstract}
Open innovation is a concept, whose attributes can be perceived as naturally complementing the proximity-based offer of clusters. The purpose of this paper is to investigate the potential role of clusters as intermediaries of open innovation for cluster members. A literature review and an exploratory study were performed, involving in-depth interviews with experts in the field of innovation and clusters in Poland. This article conceptually links open innovation and clusters, proposes and categorizes roles of clusters as open innovation intermediaries, as well as indicates factors that might affect the successful adoption of this role. Furthermore, it points out that clusters could not only manage and mediate their network of members but also shape and co-create a broader open innovation ecosystem. The findings contribute to a comprehensive understanding of the potential roles of open innovation intermediaries in regard to clusters in the context of transitioning economies. With clusters playing the role of an open innovation intermediary, public support at cluster level could increase the openness to cooperation not only for member companies but all participants in the regional innovation ecosystem.
\end{abstract}

Keywords: clusters, cluster initiative, open innovation, innovation ecosystem, innovation intermediary, open innovation intermediary, innovation policy

\section{INTRODUCTION}

The strategic documents of the European Union and Poland (the Horizon 2020 Research Program and the Strategy for Responsible Development, respectively) point to the need to support economic development based on regional and local specializations, especially through clusters. Clusters defined as "a geographical concentration of interrelated companies, specialized suppliers, service providers, companies operating in related sectors and

1 Marita McPhillips, Dr.Eng., Gdansk University of Technology, Faculty of Management and Economics, Narutowicza 11/12, Gdansk, Poland, e-mail: marita.mcphillips@pg.edu.pl (ORCID ID: 0000-0003-1181-669X). 
related institutions in specific fields, cooperating and competing with each other" (Porter, 1990) gained importance by generating positive external effects and increasing the competitiveness of regions. The beneficial role of geographical, cognitive, and social proximity in relation to industrial clusters has long been apparent. Clusters seem to play a significant role in creating the conditions necessary for successful integration of enterprises, in particular in innovation cooperation. One of the concepts that is gaining importance in the context of innovation cooperation between various entities is open innovation. Chesbrough (2003) defines open innovation as "using intentional inflows and outflows of knowledge to accelerate internal innovation and expand markets for external innovation applications." Therefore, it is an approach to innovation in which partnerships, and combining the internal and external resources of the company are used to create new ideas and technologies. In recent years there has been a significant increase in the number of scientific publications in the field of open innovation, presenting the results of quantitative and qualitative research (e.g., Dahlander \& Gann, 2010; Chesbrough \& Bogers, 2014). Various authors have accumulated and listed numerous potential benefits from implementing an open innovation model at the forefront with an increase in the ability of companies to implement innovation.

In this context, the management of innovation cooperation in multistakeholder relations becomes a key issue. Several studies indicate a special role of network intermediaries supporting innovation cooperation and open innovation among enterprises (Lee et al., 2010).

This article refers to the concept of a proxy - an intermediary organization - to be a defining feature of cluster initiatives, which carry out various intermediary roles on behalf of their members. Howells (2006) characterizes intermediaries as organizations that act as brokers in the innovation process between two or more parties by providing services, including provision of information about potential collaborators; as mediators between already collaborating actors; and as monitors, funders and supporters by other means of their network members. Scholars have called cluster initiatives "innovative intermediaries" because of their mediating position between regional authorities, business, and academia (Kivimaa et al., 2019). Those type of intermediaries may especially originate in response to market restructuring and new modes of regulation, and to fill institutional gaps (Moss, 2009). On the other hand, more and more researchers argue that cluster initiatives should not be understood as fitting into the narrow sectoral view of an intermediary organization but be considered as regional ecosystems of related industries with a broad array of inter-industry interdependencies (Delgado et al., 2016). These linkages tend to show, for instance, in terms of similar location patterns, occupational and technological needs and knowledge spillovers, 
and cross-sector investments. Innovation intermediaries are, therefore, seen to be central to creating and maintaining a successful innovation ecosystem (Sieg et al., 2010; De Silva et al., 2018).

The direct relationship between clusters and open innovations has not yet been the subject of special attention in the literature, with a few exceptions like Chesbrough and Bogers (2014) who identified some higher levels of analysis such as networks and regions as important research opportunities and described a strong need to better understand intra- organizational attributes of open innovation, and Di Minin and Rossi (2016) who underline the significance of clusters for a stimulating innovation ecosystem and argue that clusters are particularly suitable as vehicles and vectors of open innovation.

Moreover, despite several extensive studies on open innovation in a Polish context (Sopińska \& Mierzejewska, 2016; Stanisławski, 2017), the phenomenon of open innovation generally seems to be under-researched in comparison with the number of studies on this topic in the foreign literature. In addition, not all applications and comments regarding the use of open innovations in other European countries can be adapted to a Polish context. This is due to the specifics of the domestic market and entities operating on it, including the low level of social trust.

The purpose of this paper is to investigate the potential role of clusters as intermediaries of open innovation for cluster members. It was, along with the above considerations, the basis for formulating the research questions for the exploratory study, which are:

RQ1. Could clusters become intermediaries of open innovation for cluster members?

RQ2. What roles could clusters take as intermediaries of open innovation for cluster members?

$R Q 3$. What factors might affect the successful adoption of a role of an intermediary of open innovation by clusters?

From a theory point of view, considerations of open innovation in the context of clusters can be based on various approaches. This article refers to the theory of dynamic capabilities (Teece, 2014; Bogers, 2011), providing perspectives for understanding the role of open innovation, connecting the activities of various stakeholders, taking place across organizational boundaries of enterprises.

The paper proceeds as follows. In the next section, the basic premises and the connections of open innovation and cluster concepts with regards to innovation ecosystems, and the role of intermediaries are discussed. Thereafter, the qualitative research design is presented. In the next sections, 
the clusters' potential role as open innovation intermediaries is analyzed and discussed. Finally, conclusions, contribution, and limitations are presented.

\section{LITERATURE REVIEW}

\section{Open innovation - basic premises}

Open innovation is defined as "a distributed innovation process that involves purposively managed knowledge flows across the organizational boundary" (Chesbrough \& Bogers, 2014). Put simply, it describes the phenomenon of companies making use of externally generated ideas and technologies in their own businesses and allowing unused internal ideas and technologies to be applied by others in their businesses. The idea that companies should leverage external knowledge sources and engage a broad network of external partners in order to promote innovation has prevailed in the discourse of academia and the business press for the past decade or more (Laursen \& Salter, 2006). In expanding firm boundaries, open innovation affects companies' business models and strategies (Chesbrough \& Appleyard, 2007; Chesbrough \& Bogers, 2014). Open innovation is also expected to facilitate access to resources, knowledge and competencies otherwise unavailable to the firm, as well as to enable companies to better realize the strategic potential of the active commercialization of knowledge (Faems et al., 2010; Gassmann et al., 2010; Huizingh, 2011).

There is no specific definition of open innovation activities, but rather there exists a wide range of cooperative undertakings - with different levels of maturity and openness. Open innovation suggests the execution of practices related to external knowledge acquisition and commercialization which range from the involvement of lead users, through R\&D purchases, venturing, and licensing agreements to even the free revealing of inventions (Burcharth et al., 2014, Stanko \& Henard, 2017). None of these types of cooperation practices are clearly identifiable and partly overlap. In addition, the tools used to implement open innovations are very diverse in terms of their assumptions and the goal to be achieved as a result of their application. The logic of openness integrates knowledge flows with pecuniary and nonpecuniary mechanisms, as well as inward and outward flows. Most studies distinguish between the dimensions of inbound - the outside-in perspective related to in-licensing agreements, crowdsourcing, customer involvement, and R\&D purchases - and outbound - the inside-out perspective related to out-licensing agreements, free revealing and spin-offs. A third dimension is the coupled one, which implies combined knowledge inflows and outflows 
between partners in the innovation process - a perspective that involves any combination of the above-mentioned practices, alongside strategic alliances, consortia, networks, ecosystems, and platforms (Chesbrough \& Bogers, 2014; Dahlander \& Gann, 2010).

Despite the expected gains of open innovation, there are several challenges involved. Many companies struggle with the implementation of open innovation. This is due to many interrelated factors that go beyond the macroeconomic or societal context to encompass organizational and individual factors. There are industrial differences with regard to the practice of open innovation too. Existing evidence suggests that companies are more prone to engage in open innovation if they belong to high technology-intense, globalized, and manufacturing sectors. Furthermore, larger companies seem to be more open as they enjoy the benefits of having more diversified innovation portfolios, access to funds and formal structures for licensing intellectual property and external participations, in comparison to their small and medium-sized counterparts (Van de Vrande et al., 2009).

In the open innovation model, companies search for knowledge, which is a source of competitiveness and a prerequisite for successful participation in international trade and investment. However, it requires specific circumstances in which to be created, modified, and diffused. Much knowledge remains in a tacit form, limited to certain places. Such open innovation also requires social interactions, which are more efficient in the proximity since tacit knowledge is not well transmitted over distance. The more tacit the knowledge is, the more important spatial proximity and direct, face-to-face contact becomes.

\section{Clusters - main features}

From a theoretical point of view, the idea that a certain number of firms and industries within a defined geographical space can join forces and improve their productivity by gathering together or, in other words, by "clustering," is hardly new or peculiar to contemporary literature. According to Porter (1990), proximity might create a stimulating business environment where companies can thrive, while at the same time drawing from each other's pool of skilled labor and expertise to source inputs, acquire knowledge and information and, therefore, generate complementarities.

Clusters are often facilitated by cluster initiatives led by cluster coordinators (Solvell, 2003). The concepts of cluster and cluster initiative are interrelated, and the word cluster is also commonly used to describe cluster initiative. Scientific literature points to this duality (Jankowska \& Gotz, 2017), explaining that such simplification seems inevitable and is commonly used. 
The benefits obtained by companies located in a developed cluster are widely discussed (Porter, 1998; Morosini, 2004; Bembenek \& Kowalska, 2016), among others: a larger local market for products and services, reduction of transport costs, easier access to resources, competitive environment that increases motivation, specialized human resources. It is emphasized that the proximity of companies in the same industry enables them to exchange knowledge and ideas through direct contact and the flow of employees (Carlino, 2001). The results of empirical studies confirm a higher level of innovation in companies located in clusters (Zimmermann, 2001; Gorynia \& Jankowska, 2008; Kowalski, 2013). The cluster is seen as a source of many benefits for members operating in its structures. The scale of these benefits depends on many external and internal factors towards the cluster, but they all seem to relate to various forms of broadly understood knowledge spillovers.

The key feature of clusters is their heterogeneity. It is often stated that each cluster is so specific that one cannot draw far-reaching conclusions based on its analysis as to the functioning of other systems (Mariotti et al., 2008). This is a significant challenge for researchers. There have been repeated attempts to conduct research based on a comparative analysis of many cluster cases, including at the European level (NGPExcellence - Cluster Excellence in the Nordic Countries, Germany, and Poland, 2011) and Polish (PARP, 2012, 2014). The diversity of cluster structures resulting from local, industry, public policy, etc. is, however, so significant that the results of these studies cannot be generalized. In this context, researchers encounter a number of problems: from defining the categories of tested attributes, difficulties in determining measurement ranges, to issues of usefulness of results for practical purposes. The benefits of clustering may either be passive externalities, derived from companies simply being co-located or be active externalities, for which colocated companies have to engage in actual collaboration with one another. However, none of these proximity dimensions necessarily grant firms automatic access to locally residing tacit and explicit knowledge, nor do they straightforwardly lead to active externalities, as these require collective action of clustered firms. Hence, firms have to form and maintain trustful and cooperative social relationships. Without these kinds of relationships, firms in clusters may have a difficult time attaining cluster benefits. Link et al. (2007) and Engel (2015) present the essential role of cluster organizations in creating the conditions necessary for the successful integration of enterprises, in particular, SMEs in external cooperation. There is empirical evidence highlighting the impact of cluster management in building specific networks for innovation based on cooperation and knowledge sharing (Bahlmann \& Huysman, 2008; Castro, 2015). In particular, research on French, German, and Swedish clusters 
confirms the positive impact of cluster management on the innovativeness of member companies, for example, Berthiner-Poncet et al. (2018).

Benefits resulting from the cluster's innovation can be analyzed at various levels (cluster members, cluster as an organization, region, and country) and from different perspectives. By their very nature, clusters create an environment for effective cooperation between partners. The effects of innovation activities are understood broadly, not only through the direct results of cooperation, but also from the perspective of partners' involvement, actions taken, and resources mobilized. Veeckman et al. (2013) indicate that the result of innovation, such as a product or service, is closely related to the innovation environment and the chosen innovation approach. In addition, Femenias and Hagbert (2013) indicate that innovation networks can create different values for different entities. The authors suggest a wide spectrum of results that include tangible and intangible innovations. The effects of innovation activity within clusters are directly available to cluster members participating in them, thus increasing their innovation potential. Nonetheless, it is not always easy for cluster initiatives to cross the organizational, cognitive, and cultural boundaries of each actor to create a common identity or a new area of shared knowledge (Castro Gonçalves, 2012). Cluster initiatives, improving the cooperation between different types of entities in clusters, improve innovation, and financial results of the involved cluster companies. The effects of the activities depend, to a large extent, on the cluster organization. Research shows significant differences in the effectiveness of cluster initiatives, leaving room for benchmarking, and learning between clusters (Morgulis-Yakushev \& Sölvell, 2017). Brosnan et al. (2016) even suggest viewing clusters through the prism of the process of clustering and hence regard them as a process rather than an organizational form. The knowledge environment present in clusters can thus be defined as an ecosystem conducive to broadly defined knowledge processes.

Notwithstanding differences in approaching the issues of financing, externalities, and learning, all the analyses agree upon the fact that persistent communication, knowledge sharing, and transparency are at the heart of successful clustering. Unsurprisingly, this aspect might well turn clusters into enablers of dynamics that Henry Chesbrough defined as open innovation $(2003 ; 2006)$.

\section{Clusters and open innovation - searching for relations}

Open innovation is foreseen as a tool for tackling the key issues that prevent Europe from exploiting its full potential in connection to innovation performance, innovation transfer and innovation scale-up. (European 
Commission, 2018) Given the surrounding uncertainty and yet high expectations for open innovation, researchers, policymakers, and industryinsiders tend to attribute an important role in its development to clusters (West $\&$ Bogers, 2014). The complementarity of cluster concepts and collaborative innovation seems indisputable. Clusters use inter-organizational network effects, knowledge flows, and external effects, in addition to cooperation in groups of companies as well as between companies and other institutions. Monfardini et al. (2012) prove that the innovation capacity of companies can be supported by external entities, such as innovation agencies, technology transfer institutions, incubators, and cluster organizations. In this light, we can assume that clusters can potentially play an important role in supporting open innovation (Chiaroni et al., 2011; Huang et al., 2015; Lee et al., 2010). One of the very few empirical studies directly addressing the topic of open innovations and cluster activities (Berthinier-Poncet, 2014) showed that the implementation of these practices in the cluster positively affects the dynamics of learning and innovation of member companies.

Geographical proximity is one of the distinctive features of cluster systems that seem designed to benefit from and, at the same time, to productively channel the advantages offered by open innovation (Di Minin, \& Rossi, 2016). For example, local companies can exploit geographical proximity to maximize the advantages offered by promoting greater openness and a culture of exchange. Much in the same way, the accurate knowledge of the local context and the presence "on the ground" of many firms involved in a cluster can allow them to quickly scout for new innovative initiatives and immediately capitalize on them, as well as to exploit each other's pool of qualified and professional expertise. In addition, since open innovation is largely reliant on mutual exchanges of sensitive information - turning trust into a key factor - local connections promoted by clusters can significantly encourage firms to exchange knowledge without excessive reserves and, therefore, favor circulation of innovative solutions and best practices alike.

In the Polish context, Sopińska and Mierzejewska (2017) argue that innovation companies operating on the Polish market are only at the beginning of the process of opening their innovation activities. Moreover, initiating open innovation activities means, among other things, the need to take greater than usual risk. Researchers describe phenomena that affect the reluctance to use open innovations in companies, including not-inventedhere syndrome, not-sold-here, or only-used-here.

These barriers apply in particular to SME companies, although research shows that SMEs can potentially benefit more from open innovation activities than large companies (Parida et al., 2012). Pichlak (2012) emphasizes that most large and medium-sized enterprises simultaneously generate and 
acquire new technical knowledge or buy and sell intellectual property rights (licenses, patent and copyright or trademarks). However, the exploration of the environment by SMEs is largely due to the lack of available resources, and therefore the relatively low propensity of these companies to conduct their own research and development activities. The specifics of SME entities include relatively low capital intensity of projects, low knowledge in the field of management, lack of permanent R\&D departments, short-term research and development projects, limited access to external financing, reluctance of entrepreneurs to exchange information and new technical solutions and technology. (Stanisławski, 2014). The above-mentioned conditions indicate rather "closed" nature of companies in the SME sector. Eliminating barriers might be a decisive condition for an increase in the propensity of SMEs to apply the concept of open innovation. Teirlinck and Spithoven (2013) confirm that SMEs seem to be more likely to launch new products or services if they work with external partners. Unlike large companies, SMEs use different types of open innovation simultaneously during this process. To absorb external knowledge, SMEs must be able to find the right partners. In practice, this means that organizations need to move away from closed models to more open attitudes in which cooperation and exchange of experience between various market participants dominate, e.g. as part of cluster initiatives, regional innovation systems, and relationships between business and science, administration and society (Carayannis \& Campbell, 2011). The more external the sources of knowledge acquisition, the greater the enterprise's willingness to reach for the benefits of the open innovation model and knowledge transfer from/to the environment (Laursen \& Salter, 2004), and the greater the likelihood of finding a suitable partner for new innovations if there are many potential partners in the network (Katzy et al., 2013; Sisodiya et al., 2013).

From an inter-organizational perspective, the effectiveness of open innovation depends on more than just the flow of knowledge in the early stages of the innovation process (e.g., Dahlander \& Gann, 2010; Huizingh, 2011; Chesbrough \& Bogers, 2014). The open innovation model often requires companies to organize or to actively participate in innovation ecosystems that integrate a diverse set of entities at different stages of the innovation process (West \& Bogers 2014). Therefore, the key issue is managing cooperation in these dynamic relationships.

Researchers indicate the special role of network intermediaries supporting innovation cooperation and open innovation among enterprises (Lee et al., 2010). Studies especially highlight the impact of cluster management in building specific networks for collaborative innovation and knowledge sharing (Bahlmann \& Huysman, 2008; Bell, 2009; Castro, 2015). In particular, research 
on French, German, and Swedish clusters has confirmed the positive impact of cluster management on the innovation potential of member companies (e.g., Berthinier-Poncet, 2014). In this sense, clusters seem to be a privileged space for observing the inter-organizational dynamics of innovation cooperation. If the cluster's goal is to strengthen the innovation capacity of the actors involved, activities aimed at achieving this goal must be initiated as part of the cluster initiative. In this case, the cluster initiative often takes over the task of coordinating innovation processes for its participants. Some methods used in a cluster initiative in this context do not differ much from the classic methods of managing innovation used internally by companies; others are specific to the cluster context, mainly in terms of the networking component. Nevertheless, the functioning of an open innovation network is related to expenditure as well as to potentially negative aspects (Czakon, 2014). That could include coordination costs, as cooperation within a growing group of companies increases the needs for communication and control. Cluster support may contribute to reducing the significance of the above barriers and making better use of opportunities related to undertaking open innovations.

Recommendations for undertaking innovation activities in clusters were reflected in the cluster management standards, which were developed in 2014 by a group of experts, in cooperation with the Polish Agency for Entrepreneurship Development (PARP). Standards related to the innovation of clusters assume that the cluster coordinator will actively engage in innovation processes in the cluster, including processes of Open Innovation and User-Driven Innovations (Piotrowski, 2014). According to the standard, the scale of the coordinator's activity should be adequate for the level of cluster development and the needs of its members (Kępka \& Kacperek, 2017). However, there is an opinion among Polish researchers (e.g., Moszkowicz \& Bembenek, 2017) that although Polish cluster initiatives implement more and more actions aimed at improving the innovation of their members, the potential of clusters in this respect does not seem to be fully used. It seems that Polish clusters have significant potential to undertake open innovations for the benefit of their members but have not yet included them in a permanent system of initiation, coordination and evaluation, necessary not only for the effectiveness but also for the repeatability of joint innovation processes.

\section{METHODOLOGY AND RESEARCH METHODS}

This article is laying the ground for linking the concepts of clusters and open innovation. In order to underline the theoretical conclusions in the context 
of Poland, an empirical study was performed, where a qualitative research method was used. The research questions were:

\section{RQ1.Could clusters become intermediaries of open innovation for cluster members?}

RQ2. What roles could clusters take as intermediaries of open innovation for cluster members?

RQ3. What factors might affect the successful adoption of a role of an intermediary of open innovation by clusters?

This study was exploratory, planned as the first step in a three-part, nationwide mixed methods project, which has been undertaken subsequently. The data gathered through interviews were checked against theoretical explanations to validate the conceptual framework and to develop the next stage of the project, which was important since the paper addresses an underexplored topic (Edmondson \& McManus, 2007).

The study was conducted through 12 in-depth semi-structured expert interviews since there has not been any in-depth analysis made in Poland on this topic yet. The major advantage of this approach is the possibility of the synergistic use of the knowledge and the experience of experts to solve problems that are not answered in the currently available literature. Semistructured interviews were carried out to enable the researcher to answer one or more of their research questions (Taylor et al., 2015). Open-ended questions allowed the experts to freely voice their experience and to minimize the influence of the researcher's attitudes and previous findings (Creswell et al., 2007). The analysis of the interview data followed a simplified version of the general steps of qualitative data analysis described by Creswell (2009).

Interviews were conducted with 12 experts, "handpicked" and selected on the basis of their wide experience in the field of clusters and innovation. The sampling method ensured that the chosen experts were all suited to the purpose of the research. The experts had science, business, or government administration backgrounds and broad theoretical and practical knowledge on issues connected to cooperation and innovation processes. The selection of experts was purposeful and was based on predefined criteria, tailored to the specific backgrounds of the experts. Four representatives of academia were chosen on the basis of significant scientific achievements in the area of clusters and innovation as well as on the basis of their experience in empirical research on Polish cluster initiatives. Four representatives of administration were chosen on the basis of their broad experience in implementing cluster and innovation-based policy at the national or local level. Four 
representatives of the business support sphere were chosen on the basis of their substantive experience in direct support of cluster initiatives in terms of their innovation activity. All 12 experts were subject to additional criteria connected to their authority, national recognition and influence in the field of the study assessed, i.e. through their involvement in committees actively working towards cluster development in Poland: The Cluster Policy Working Group at the Polish Agency for Enterprise Development, Clusters Club at the Ministry of Economy, Benchmarking of Clusters in Poland, Polish Clusters Association, etc. Experts were "cherry picked" from a pool of the most recognized individuals within the research area.

Table 1. Selection criteria for experts taking part in the study as respondents of semi-structured interviews

\begin{tabular}{|c|c|c|c|}
\hline Background of experts & Academia & Administration & Business support \\
\hline $\begin{array}{l}\text { No of experts in the } \\
\text { study }\end{array}$ & 4 & 4 & 4 \\
\hline $\begin{array}{l}\text { Common selection } \\
\text { criteria }\end{array}$ & \multicolumn{3}{|c|}{$\begin{array}{l}\text { broad theoretical and practical knowledge on clusters, } \\
\text { cooperation and innovation processes } \\
\text { authority, national recognition, and influence in the } \\
\text { field of the study. }\end{array}$} \\
\hline $\begin{array}{l}\text { Selection criteria specific } \\
\text { to the area }\end{array}$ & $\begin{array}{l}\text { significant } \\
\text { scientific } \\
\text { achievements } \\
\text { in the area of } \\
\text { clusters and } \\
\text { innovation } \\
\text { experience } \\
\text { in empirical } \\
\text { research on } \\
\text { Polish cluster } \\
\text { initiatives }\end{array}$ & $\begin{array}{l}\text { broad experience } \\
\text { in implementing } \\
\text { cluster and } \\
\text { innovation-based } \\
\text { policy at national } \\
\text { or local level }\end{array}$ & $\begin{array}{l}\text { substantive } \\
\text { experience in } \\
\text { direct support of } \\
\text { cluster initiatives } \\
\text { in terms of } \\
\text { their innovation } \\
\text { activity }\end{array}$ \\
\hline
\end{tabular}

Interviewed experts answered questions according to an open interview scenario prepared for this study but were encouraged to make broad statements associated with the study area. The interview questions concerned matters including: the understanding of the notion of open innovation, the readiness of cluster initiatives in Poland to become intermediaries of open innovation for their members, the roles that cluster initiatives could take as open innovation intermediaries and factors that could influence the process of taking on such a role by cluster initiatives. 


\section{ANALYSIS}

The first matter in the study concerned the definition of the concept of open innovation as understood by experts. All of the experts (12 of 12) had earlier encountered this concept and were able to define it. However, experts from different backgrounds presented differences in their responses, emphasizing different elements of the concept. In particular, representatives coming from administration highlighted the importance of outbound processes within the framework of open innovation, i.e. the commercialization of solutions generated within the company that do not fit into their current strategy, e.g. through sharing or selling the solution to a third party. Representatives coming from academia or business rather tended to underline the importance of inbound processes of open innovation, i.e. companies using external knowledge as a source of internal innovation.

All of the interviewed experts (12 of 12) agreed that cluster initiatives can form an environment that supports open innovation activity and cluster initiatives are, or could become, open innovation intermediaries for their members. Experts listed activities which, according to them, could comprise potential open innovation activities in cluster initiatives, including: advanced methods of supporting open innovation processes such as living labs and user-driven innovation, but also simpler activities aimed at enhancing the usage of the innovation ecosystem by cluster companies such as organizing cooperation projects.

The cluster initiative's main role as an open innovation intermediary, according to all experts, is to be an active organization and to collaborate with universities, large and medium-sized firms, but also with small or micro firms, which constitute the majority of most cluster initiatives in Poland. The role implies activities such as engaging in basic communication activities and associated training connected to innovation, acting as a networking agent, and engaging in applied research to technology service provision. This article proposes that cluster initiatives fulfilling this role can be categorized as Ecosystem Agents.

Another role of the cluster initiative as an open innovation intermediary was associated with working towards strengthening connections in the innovation ecosystem, in which knowledge and relations with the ecosystem actors enable cluster initiatives to bring together key players for projects, especially those that are EU funded. Another example is creating a product/ service platform for engaging technological partners from within and from outside of the initiative. Those types of activities increase the chances of being successful both in terms of securing funding as well as delivering 
output. This article proposes that cluster initiatives fulfilling this role can be categorized as Ecosystem Builders.

For 8 of 12 experts interviewed, an important next step for the cluster initiative is to actively shape the innovation ecosystem, enhancing its reach and its significance through written strategic communication, expert advisory groups, and influence made through external bodies. Those activities potentially have the most positive impact on network value generation. Such influences should also be made in collaboration with other types of innovation intermediaries and like-minded organizations, which in turn become project collaborators leading to strengthening the innovation ecosystem. This article proposes that cluster initiatives fulfilling this role can be categorized as Ecosystem Shapers.

Table 2. Analysis of roles of cluster initiatives as open innovation intermediaries indicated by experts in the study (coding) and category proposed in this article

\begin{tabular}{ll}
\hline $\mathbf{2}^{\text {nd }}$ stage coding & $\begin{array}{l}\text { Category proposed in the } \\
\text { article }\end{array}$ \\
\hline $\begin{array}{l}\text { acting on behalf of cluster member companies as } \\
\text { a consulting intermediary } \\
\text { brokering between two or more parties by providing } \\
\text { services, including provision of information about } \\
\text { potential collaborators }\end{array}$ & $\begin{array}{l}\text { Cluster initiative as an } \\
\text { open innovation Ecosystem } \\
\text { Agent }\end{array}$ \\
\hline $\begin{array}{l}\text { strengthening connections between cluster member } \\
\text { companies and ecosystem actors, creating new }\end{array}$ & \\
$\begin{array}{l}\text { connections } \\
\text { mediating between already collaborating actors, } \\
\text { bring together key players for projects }\end{array}$ & $\begin{array}{l}\text { Cluster initiative as an } \\
\text { open innovation Ecosystem } \\
\text { monitoring, funding and supporting the connections }\end{array}$ \\
in the ecosystem & \\
\hline $\begin{array}{l}\text { enhancing the reach of the ecosystem, its } \\
\text { significance, influence and potential gains of its }\end{array}$ & $\begin{array}{l}\text { Cluster initiative as an } \\
\text { members }\end{array}$ \\
\hline
\end{tabular}

The role of the cluster initiatives as an open innovation intermediary and the scope of activities will certainly be different according to external and internal factors that affect a particular initiative. External factors with a potential influence were ascertained by the experts: the most obvious of these factors being the type of industry. Other factors identified in the study included: the relative importance of stages within the innovation process and the organization of a regional innovation ecosystem. Experts indicated regions in which a lack of active technology transfer institutions resulted in cluster initiatives filling the gap in the market for this type of 
service (and, thus, taking on the responsibility of being the active technology transfer institution for that region and becoming the most important node in a regional innovation ecosystem). In other cases, there was high activity of technology transfer institutions, and cluster initiatives cooperated with those institutions rather than replaced them. According to the experts, the size of a company and whether the company is an SME is not an important factor which affects the process of open innovation in clusters, since most of the companies in Polish initiatives are rather small. While most of the firms described in early works on open innovation were large multinational firms, it has become apparent that small and medium-sized firms (SME) are also opening up their innovation process.

Experts believed that some internal factors might be important for the cluster initiatives to take on a role as an intermediary, the two most commonly named being: the maturity of the cluster initiative and the organizational activity of the cluster initiative. A complex of indicators can fall within the scope of maturity with experts indicating the "age" of the initiative, its size, and what proportion of its members were SMEs. The scope of organizational activity included: the significance of innovation in the initiative's strategy, what proportion of member companies were involved in innovation activities organized by the cluster initiative, and the lead role of cluster managers in initiating innovation projects.

Table 3. Factors that might influence a cluster initiative as an open innovation intermediary according to the experts in the study

\begin{tabular}{|c|c|}
\hline $\begin{array}{l}\text { Most important factors external } \\
\text { to cluster initiative as indicated by } \\
\text { respondents }\end{array}$ & $\begin{array}{l}\text { Most important factors internal } \\
\text { to cluster initiative as indicated by } \\
\text { respondents }\end{array}$ \\
\hline $\begin{array}{l}\text { type of industry } \\
\text { the relative importance of stages within } \\
\text { the innovation process } \\
\text { organization of regional innovation } \\
\text { ecosystem }\end{array}$ & $\begin{array}{l}\text { number of years of initiative operating } \\
\text { ("age" of the initiative) } \\
\text { size of cluster initiative (number of } \\
\text { participants) } \\
\text { proportion of SMEs members in the } \\
\text { initiative } \\
\text { significance of innovation in the } \\
\text { initiative's strategy } \\
\text { proportion of member companies } \\
\text { involved in innovation activities } \\
\text { lead role of cluster managers in } \\
\text { initiating innovation projects }\end{array}$ \\
\hline
\end{tabular}


Many barriers to the performance of cluster initiatives as open innovation intermediaries were identified by the interviewees, the most important being distrust between members. Experts estimate different sources of this barrier: relating it to the attitudes of individual companies and/or cultural determinants of the country. This barrier was perceived to be far more important than any other, including IPR protection and technological problems. Indications of distrust as the most important barrier implied the need to stimulate increased activity of cluster initiatives in the field of open innovation called for by experts. The most common potential drivers of open innovation performance in cluster initiatives that the experts indicated include access to best practices of open innovation projects within the same industry and public financial support for organizing open innovation activities.

\section{DISCUSSION OF RESULTS}

There was no doubt among experts interviewed in the study that a cluster initiative as a governing body of a cluster could become an intermediary of open innovation for its cluster members (Q1). Cluster initiatives seem to influence the emergence of open innovation activities by member firms through increased trust and reduced information asymmetries. (Nestle et al., 2019). It was to be expected, in light of the fact that some cluster initiatives in Poland are already actively supporting the innovation processes in their member companies. Innovation intermediaries appear to be developing new practices in environments where risk and uncertainty are high and where sophisticated management principles have to be developed (Agogue et al., 2017). Opening the processes of innovation in an environment of geographical proximity, trust, and effectively managing an organization could be, therefore, a relatively small step in advanced cluster initiatives. But not all initiatives in Poland are at the moment equipped with competencies needed for that kind of activity. A need to finance operations from their own very limited resources means that most of them, at present, limit their innovation activity (Bembenek, 2017).

Regarding the second research question (Q2), on the basis of the literature and experts' responses, this article identifies practices and proposed roles that cluster initiatives could take as intermediaries of open innovation. The identified practices range from simple communication of a potential innovation partner proposal to a broad, multithreaded strategic action aimed at expansion of the whole innovation ecosystem. The role of open innovation intermediaries seemingly extends from linking parties for collaboration, to setting up and 
mediating relationships and bridging a wide array of knowledge, competency and capability gaps (Smedlund, 2006; Edler \& Yeow, 2016).

This article proposes a number of roles for cluster initiatives as open innovation intermediaries. The roles were based on the range of practices proposed by the experts and categorized from the narrowest to the broadest view of the impact on the ecosystem and therefore value generated: from an Ecosystem Agent, through an Ecosystem Builder to an Ecosystem Shaper. Ecosystem Agents in this context are cluster initiatives that act as knowledge repositories that introduce new combinations of knowledge and also make knowledge-based contributions when providing solutions to their clients (Howells, 2006), or in this situation - cluster members. This article proposes the category of Ecosystem Builders to those cluster initiatives as, among the varied types of engagement by innovation intermediaries (Howells, 2006), their interaction in collaborative projects represents one of their more complex, enriched and involved roles as they (in addition to developing and supporting the partnership) engage in the co-development of innovative activity with collaborators, e.g. in an EU-funded international project or through creating a product platform. Ecosystem Shapers, in our study, are those cluster initiatives that, in addition to other roles, are central to creating and maintaining a successful innovation ecosystem (Sieg et al., 2010). Collaboration in an ecosystem is difficult when partners have diverse interests, goals, and motivations. One way of overcoming this is through shaping the interests of actors within an innovation system to increase the chances of reaching a shared understanding and mutuality between the participating actors, which is important for successful collaboration (Wallin and von Krogh, 2010; Tjong et al., 2015). Thus, innovation intermediaries, in collaboration with other actors in the innovation system, often engage in helping to shape the strategic policy direction, which results in convergence around the interests of actors within the region. Some researchers even argue that developing a consensus is one of intermediaries' key functions (Meyer et al., 2019).

Regarding the factors that might affect the successful adoption of a role of an intermediary of open innovation by clusters (Q3), during the study, a list of potential external and internal factors (in relation to a cluster initiative) was composed. The external factors included technological conditions, e.g. the type of industry. It is in line with previous studies indicating that open innovation practices occur more often in high-tech sectors such as the ICT industry (Christensen et al., 2005; Dittrich \& Duysters, 2007), biotechnology (Fetterhoff \&Voelkel, 2006), financial services (Fasnacht, 2009) and in large enterprises and multinational corporations (Chesbrough, 2006). Regional conditions also might be a factor affecting the process of open innovation. The cluster initiative itself has a limited influence on the composition of 
the regional ecosystem but a greater one in developing stronger relations between ecosystem members. Lee et al. (2010) indicate that the key determinant of open innovation implementation is the existence of a network of links between institutions promoting cooperation and technology transfer. In Polish conditions, companies are very reluctant to cooperate with scientific and research institutions (Sopińska \& Mierzejewska, 2017).

Internal factors, affecting the process of open innovation in clusters identified in the study, pointed at the maturity of cluster initiatives and the organizational activity of the initiatives. It is in line with the results of a benchmarking of cluster initiatives carried out in several European countries, which showed a strong correlation between the age and size of the cluster and the impact of cluster organization activities on the business and research and development activities of SMEs (Lammer-Gamp et al., 2011). The benchmarking study assumed, however, that the majority of cluster organizations' activities will be co-financed from public funds, like takes place in most European countries, and that as their maturity increases, clusters will increase their competence in cooperation coordination. Instability in the financing of cluster initiatives in a Polish context might affect the organization of their activities, the difficulties in undertaking long-term innovation activities, and balancing the divergent interests of different groups of stakeholders. With no or minimal external support, Polish cluster initiatives must decide on the scope of innovation services offered, taking into account their business model and financial stability.

\section{CONCLUSIONS}

The findings of the study provide an insight into the role of cluster initiatives as proxies - open innovation intermediaries - that might support open innovation within initiatives themselves as well as in broader innovation ecosystems. This article has argued that the concept of open innovation, as it was originally coined and as it has been applied by companies and institutions worldwide, has a fundamental regional dimension. Geographical proximity can represent a key competitive advantage and clusters can achieve such advantages by becoming intermediaries of open innovation, a paradigm that works particularly well thanks to the structure of clusters themselves. Eventually, geographical proximity also favors the development of trust, an intangible element that stimulates the generation of best practices and, even more importantly, encourages firms to diffuse their internal learning and research. Cluster initiatives not only have certain features of the knowledge base, such as universities, research institutes or a pool of highly qualified 
employees but also provide the necessary elements to facilitate knowledge development, dissemination, and accumulation, such as various cooperation platforms, social networks, and active coordinator support. Indeed, cluster initiatives, enhancing, managing and mediating the process, might act as a central element in an open innovation ecosystem. Various ways of organizing open innovation practices can provide a source of knowledge for ecosystem members and bring companies closer in terms of potential partnership in new ventures (Radziwon et al., 2014; Chesbrough et al., 2014).

Evaluations of economic policy programs based on clusters indicate that "the success of cluster initiatives as drivers of innovation processes of companies is beyond dispute" (Kocker et al., 2017). This means that clusters contribute to accelerating innovation processes for the benefit of their stakeholders. However, the process of open innovation within cluster initiatives in Poland seems to be still at a relatively early stage of development. With the greater maturity of the cluster initiative and the increase in management experience, the cluster's potential for effective management of innovation processes in the interest of its members most probably will be growing.

Clusters can play a quasi-public role as an innovation intermediary and a central element of regional innovation ecosystems, but the need to finance activities from their own very limited resources means that they limit their innovation activities (Koszarek, 2014; Bembenek, 2017). Direct financial support for innovation activities in clusters is a standard in the majority of European countries (including other Eastern European countries, except Poland) and is recommended by the OECD as contributing to longterm economic growth. The results of research on the importance of public financial support for the innovation activity of Polish enterprises, including open innovation processes, carried out by Lewandowska (2017), show that an increase in public support for innovation activity is accompanied by an increased openness to cooperation.

\section{Implication for research and practice}

The present study contributes to the previous research on open innovation intermediaries and clusters. The findings contribute to a comprehensive understanding of the potential roles of open innovation intermediaries in regard to clusters in the context of transitioning economies. Furthermore, this study develops a framework to explore the processes through which open innovation intermediaries fill the aforementioned roles. In the context of transition economies, but also in general, SMEs often lack the innovation capabilities necessary to access and enter a business field featuring high turbulence and risk (Paliokaite, 2019). This study strongly suggests that cluster 
initiatives as open innovation intermediaries can provide effective assistance to the innovation processes of SMEs. As a consequence, cluster initiatives can be more capable of serving as a crucial compensating mechanism for a regional innovation ecosystem system. From a practical point of view cluster managers might use the proposed framework to promote the evolvement of an open innovation-friendly culture in their participating companies. Clusters should also strive to not only manage and mediate but also to shape and create an innovation ecosystem, under which extensive cooperation, with business partners, non-profit organizations, support institutions from the region and the country, affects the consolidation of inputs and higher efficiency of actions taken. Lastly, this article calls for the need to reframe policy so that it is designed to stimulate companies to organize or actively participate in innovation ecosystems that integrate a diverse set of entities at various stages of the innovation process (West \& Bogers, 2014).

\section{Limitations and further research}

This article conceptually links open innovation and clusters, proposes and categorizes the roles of cluster initiatives as open innovation intermediaries, as well as indicates potential factors that might affect the successful adoption of a role of an intermediary of open innovation by clusters. It has to be emphasized, however, that conclusions made on the basis of the literature review and an exploratory study, are to be verified in the following quantitative study. This article, empirically, is based on a small-scale, expert interviews qualitative study, which is appropriate only as an exploratory study. Future research is needed to statistically validate the finding in this study by collecting a large organization-level data set. This study was exploratory in nature as the first step in a three-part, nation-wide mixed methods project, which had been undertaken subsequently. Furthermore, the study was based in a Polish context. It is plausible to assume that factors affecting open innovation processes in cluster initiatives will vary from country to country (even region to region), reflecting each country's culture, individual systems, and institutions. Therefore, cooperation in comparative settings would clarify those factors that are likely to remain constant under different conditions, and those that would differ. Also, more work will be necessary to develop direct tools that practitioners can use to develop open innovation activity within clusters.

\section{References}

Agogue, M., Berthet, E., Fredberg, T., Le Masson, P., Segrestin, B., Stoetzel, M., Wiener, M., and Yström, A. (2017). Explicating the role of innovation intermediaries in the "unknown": A contingency approach. Journal of 
Strategy and Management, 10(1), 19-39. https://doi.org/10.1108/JSMA01-2015-0005

Bahlmann, M. D., \& Huysman, M. H. (2008). The emergence of a knowledge-based view of clusters and its implications for cluster governance. The Information Society, 24(5), 304-318. https://doi. org $/ 10.1080 / 01972240802356075$

Bell, M. (2009). Innovation capabilities and directions of development. STEPS Working Paper 33. Brighton: STEPS Centre. https://opendocs.ids.ac.uk/ opendocs/handle/20.500.12413/2457

Bembenek, B. (2017). Finansowanie rozwoju jako wyzwanie strategiczne w zarządzaniu klastrami. Nauki o Finansach, (32), 9-27.

Bembenek, B., \& Kowalska, K. (2016). SMEs development within industrial clusters-Strategic challenge for cluster management. Modern Management Review, 21(23(4)), 33-50. https://doi.org/10.7862/rz.2016.mmr.41

Berthinier-Poncet, A. (2014). Gouvernance et dynamiques d'innovation au sein d'un technopôle. Une analyse par les pratiques institutionnelles d'innovation. Management international/International Management/ Gestiòn Internacional, 19(1), 94-112. https://doi.org/10.7202/1028492ar

Berthinier-Poncet, A., Grama-Vigouroux, S., \& Saidi, S. (2018). Open innovation practices of clustered SMEs: The intermediate role of cluster governance. In W. Vanhaverbeke, F. Frattini, N. Roijakkers, \& M. Usman (Eds.), Researching Open Innovation in SMEs (pp. 275-306). World Scientific. https://doi.org/10.1142/9789813230972_0009

Bogers, M. (2011). The open innovation paradox: Knowledge sharing and protection in R\&D collaborations. European Journal of Innovation Management, 14(1), 93-117. https://doi. org/10.1108/14601061111104715

Brosnan, S., Doyle, E., \& O'Connor, S. (2016). From Marshall's Triad to Porter's Diamond: Added value?. Competitiveness Review, 26(5), 500-516. https://doi.org/10.1108/CR-05-2015-0037

Burcharth, A. L., Knudsen, M. P., \& Søndergaard, H. A. (2014). Neither invented nor shared here: The impact and management of attitudes for the adoption of open innovation practices. Technovation, 34(3), 149161. http://doi.org/10.1016/j.technovation.2013.11.007

Carayannis, E. G., \& Campbell, D. F. (2011). Open innovation diplomacy and a 21st century fractal research, education and innovation (FREIE) ecosystem: Building on the quadruple and quintuple helix innovation concepts and the "mode 3" knowledge production system. Journal of the Knowledge Economy, 2(3), 327. https://doi.org/10.1007/s13132-011-0058-3

Carlino, G. A. (2001). Knowledge spillovers: Cities' role in the new economy. Business Review Quarterly, 4(1), 17-24. https://ideas.repec.org/a/fip/ fedpbr/y2001iq4p17-26.html

Castro Gonçalves, L. (2012). Learning dynamics across boundaries of IS context: A structural perspective to support knowledge management. 
Management international/International Management/Gestiòn Internacional, 16, 41-55. https://doi.org/10.7202/1012392ar

Castro, L. (2015). Strategizing across boundaries: Revisiting knowledge brokering activities in French innovation clusters. Journal of Knowledge Management, 19(5), 1048-1068. https://doi.org/10.1108/JKM-02-2015-0050

Chesbrough, H., \& Bogers, M. (2014). Explicating open innovation: Clarifying an emerging paradigm for understanding innovation. In Chesbrough, $\mathrm{H}_{\text {., }}$ Vanhaverbeke, W., \& West, J. (Eds.), New Frontiers in Open Innovation (pp. 3-28). Oxford: Oxford University Press. http://doi.org.pl/ 10.1093/ acprof:oso/9780199682461.003.0001

Chesbrough, H. (2003). The logic of open innovation: Managing intellectual property. California Management Review, 43(3), 33-58. https://doi. org $/ 10.1177 / 000812560304500301$

Chesbrough, H. W. (2006). Open Innovation: The New Imperative for Creating and Profiting from Technology. Boston: Harvard Business Press.

Chesbrough, H. W., \& Appleyard, M. M. (2007). Open innovation and strategy. California Management Review, 50(1), 57-76. https://doi. org/10.2307/41166416

Chesbrough, H., Vanhaverbeke, W., \& West, J. (Eds.). (2014). New Frontiers in Open Innovation. Oxford: Oxford University Press. https://doi. org/10.1093/acprof:oso/9780199682461.001.0001

Chiaroni, D., Chiesa, V., \& Frattini, F. (2011). The open innovation journey: How firms dynamically implement the emerging innovation management paradigm. Technovation, 31(1), 34-43. https://doi.org/10.1016/j. technovation.2009.08.007

Christensen, J.F., Olesen, M.H., \& Kjaer, J.S. (2005). The industrial dynamics of open innovation- Evidence from the transformation of consumer electronics. Research Policy, 34(10), 1533-1549. https://doi. org/10.1016/j.respol.2005.07.002

European Commission. (2018). Proposal for a regulation of the European Parliament and of the Council establishing Horizon Europe - The framework programme for research and innovation, laying down its rules for participation and dissemination. Retrieved from https://eur-lex. europa.eu/legal-content/EN/TXT/?uri=CELEX\%3A52018PC0435

Creswell, J. W. (2009). Mapping the field of mixed methods research. Journal of Mixed Methods Research, 3(2). https://doi.org/ $10.1177 / 155868980833088$

Creswell, J.W., Hanson, W.E., Clark Plano, V.L., \& Morales, A. (2007). Qualitative research designs: Selection and implementation. The Counseling Psychologist, 35(2), 236-264. https://doi. org $/ 10.1177 / 0011000006287390$

Czakon, W. (2014). Problem granic w badaniach sieci międzyorganizacyjnych. Studia i Prace Kolegium Zarzqdzania i Finansów Szkoły Głównej Handlowej, (135), 89-98. 
Dahlander, L., \& Gann, D. M. (2010). How open is innovation?. Research Policy, 39(6), 699-709. https://doi.org/10.1016/j.respol.2010.01.013

Delgado, M., Porter, M. E., \& Stern, S. (2016). Defining clusters of related industries. Journal of Economic Geography, 16(1), 1-38. https://doi. org/10.1093/jeg/lbv017

De Silva, M., Howells, J., \& Meyer, M. (2018). Innovation intermediaries and collaboration: Knowledge-based practices and internal value creation. Research Policy, 47(1), 70-87. https://doi.org/10.1016/j. respol.2017.09.011

Di Minin A., \& Rossi M. (2016) Open innovation and clusters: Why geographical proximity matters. In K. Gretschmann, \& S. Schepers (Eds.), Revolutionising EU Innovation Policy (pp. 79-95). London: Palgrave Macmillan. https://doi.org/10.1057/978-1-137-55554-0_4

Dittrich, K., \& Duysters, G. (2007). Networking as a means to strategy change: The case of open innovation in mobile telephony. Journal of Product Innovation Management, 24(6), 510-521. https://doi.org/10.1111/ j.1540-5885.2007.00268.x

Edler, J., \& Yeow, J. (2016). Connecting demand and supply: The role of intermediation in public procurement of innovation. Research Policy, 45(2), 414-426. https://doi.org/10.1016/j.respol.2015.10.010

Edmondson, A. C., \& McManus, S. E. (2007). Methodological fit in management field research. Academy of Management Review, 32(4), 1246-1264. https://doi.org/10.5465/amr.2007.26586086

Engel, J. S. (2015). Global clusters of innovation: Lessons from Silicon Valley. California Management Review, 57(2), 36-65. https://doi.org/10.1525/ cmr.2015.57.2.36

Faems, D., De Visser, M., Andries, P., and Van Looy, B. (2010). Technology alliance portfolios and financial performance: Value-enhancing and cost-increasing effects of open innovation. Journal of Product Innovation Management, 27(6), 785-796. https://doi.org/10.1111/j.1540-5885.2010.00752.x

Fasnacht, D. (2009). Open Innovation in the Financial Services: Growing Through Openness, Flexibility and Customer Integration. Berlin: Springer. https://doi.org/10.1007/978-3-540-88231-2

Femenias, P., \& Hagbert, P. (2013). The habitation lab: Using a design approach to foster innovation for sustainable living. Technology Innovation Management Review, 3(11). http://timreview.ca/article/741

Fetterhoff, T. J., \& Voelkel, D. (2006). Managing open innovation in biotechnology. Research-Technology Management, 49(3), 14-18. https:// doi.org/10.1080/08956308.2006.11657373

Gassmann, O., Enkel, E., \& Chesbrough, H. (2010). The future of open innovation. R\&D Management, 40(3), 213-221. https://doi.org/10.1111/ j.1467-9310.2010.00605.x

Gorynia, M., \& Jankowska, B. (2008). Klastry a Międzynarodowa Konkurencyjność i Internacjonalizacja Przedsiębiorstwa. Warszawa; Centrum Doradztwa i Informacji Difin. 
Howells, J. (2006). Intermediation and the role of intermediaries in innovation. Research Policy, 35(5), 715-728. https://doi.org/10.1016/j. respol.2006.03.005

Huang, F., Rice, J., \& Martin, N. (2015). Does open innovation apply to China? Exploring the contingent role of external knowledge sources and internal absorptive capacity in Chinese large firms and SMEs. Journal of Management \& Organization, 21(5), 594-613. https://doi.org/10.1017/ jmo.2014.79

Huizingh, E. K. (2011). Open innovation: State of the art and future perspectives. Technovation, 31(1), 2-9. https://doi.org/10.1016/j. technovation.2010.10.002

Jankowska, B., \& Götz, M. (2017). Internationalization intensity of clusters and their impact on firm internationalization: The case of Poland. European Planning Studies, 25(6), 958-977. https://doi.org/10.1080/09654313.20 17.1296111

Katzy, B., Turgut, E., Holzmann, T., \& Sailer, K. (2013). Innovation intermediaries: A process view on open innovation coordination. Technology Analysis \& Strategic Management, 25(3), 295-309. https://doi.org/10.1080/09537 325.2013.764982

Kivimaa, P., Boon, W., Hyysalo, S., \& Klerkx, L. (2019). Towards a typology of intermediaries in sustainability transitions: A systematic review and a research agenda. Research Policy, 48(4), 1062-1075. https://doi. org/10.1016/j.respol.2018.10.006

Kępka, B., \& Kacperek, D. (2017). WdrażanieStandardów Zarzq̨dzania Klastrem. Poradnik dla Koordynatorów. Warszawa: PARP. Retrieved from https:// www.parp.gov.pl/component/ publications/publication/wdrazaniestandardow-zarzadzania-klastrem-poradnik-dla-koordynatorow

Koszarek, M. (2014). Supporting the development of clusters in Poland - Dilemmas faced by public policy. Prace Naukowe Uniwersytetu Ekonomicznego we Wrocławiu,(365), 103-112. https://doi.org/10.15611/ pn. 2014.365 .08

Köcker, G. M., Schneider, K., \& Grieb, B. (2017). Success through thinking out of the box: Strategic differentiation in enterprises initiated by cluster initiatives. Retrieved from https://vdivde-it.de/en/publication/successthrough-thinking-out-box

Kowalski, A. M. (2013). Znaczenie Klastrów dla Innowacyjności Gospodarki w Polsce. Warszawa: Szkoła Głowna Handlowa Oficyna Wydawnicza.

Lammer-Gamp, T., zu Kocker, G. M., \& Christensen, T. A. (2011). Clusters are individuals. Danish Ministry of Research, Innovation and Higher Education. Retrieved from https://ufm.dk/en/publications/2011/ clusters-are-individuals-creating-economic-growth-through-clusterpolicies-for-cluster-management-excellence

Laursen, K., \& Salter, A. (2004). Searching high and low: What types of firms use universities as a source of innovation?. Research Policy, 33(8), 12011215. https://doi.org/10.1016/j.respol.2004.07.004 
Laursen, K., \& Salter, A. (2006). Open for innovation: The role of openness in explaining innovation performance among UK manufacturing firms. Strategic Management Journal, 27(2), 131-150. https://doi.org/10.1002/smj.507

Lee, S., Park, G., Yoon, B., \& Park, J. (2010). Open innovation in SMEs-An intermediated network model. Research Policy, 39(2), 290-300. https:// doi.org/10.1016/j.respol.2009.12.009

Lewandowska, M. S. (2017, March) Otwarte innowacje wyzwaniem współczesnego zarzqdzania. Paper presented at "Sympozjum VII: Współczesne problemy zarzqdzania", Warszawa.

Link, A. N., Siegel, D. S., \& Bozeman, B. (2007). An empirical analysis of the propensity of academics to engage in informal university technology transfer. Industrial and Corporate Change, 16(4), 641-655 https://doi. org/10.4337/9781786432797.00014

Mariotti, S., Mutinelli, M., \& Piscitello, L. (2008). The internationalization of production by Italian industrial districts' firms: structural and behavioural determinants. Regional Studies, 42(5), 719- 735. https://doi. org/10.1080/00343400701543264

Meyer, M., Kuusisto, J., Grant, K., De Silva, M., Flowers, S., \& Choksy, U. (2019). Towards new triple helix organisations? A comparative study of competence centres as knowledge, consensus and innovation spaces. R\&D Management, 49(4), 555-573. https://doi.org/10.1111/radm.12342

Monfardini, E., Probst, L., Szenci, K., Cambier, B., \& Frideres, L. (2012). Emerging industries: Report on the methodology for their classification and on the most active, significant and relevant new emerging industrial sectors. European Commission. Retrieved from https://ec.europa.eu/research/ industrial_technologies/pdf/emerging-industries-report_en.pdf

Morgulis-Yakushev, S., \& Sölvell, Ö. (2017). Enhancing dynamism in clusters: A model for evaluating cluster organizations' bridge-building activities across cluster gaps. Competitiveness Review, 27(2), 98-112. https://doi. org/10.1108/CR-02-2016-0015

Morosini, P. (2004). Industrial clusters, knowledge integration and performance. World Development, 32(2), 305-326. https://doi. org/10.1016/j.worlddev.2002.12.001

Moss, T. (2009). Intermediaries and the governance of sociotechnical networks in transition. Environment and Planning A, 41(6), 1480-1495. https://doi.org/10.1068/a4116

Moszkowicz, K., \& Bembenek, B. (2017). Innowacyjność polskich klastrówstrategiczne wyzwanie w zarządzaniu klastrami. Organizacja i Kierowanie, (4), 27-45. https://www.ceeol.com/search/article-detail?id=719736

Nestle, V., Täube, F. A., Heidenreich, S., \& Bogers, M. (2019). Establishing open innovation culture in cluster initiatives: The role of trust and information asymmetry. Technological Forecasting and Social Change, 146, 563-572. https://doi.org/10.1016/j.techfore.2018.06.022

NGP Excellence. (2011). 24 proofs of Cluster Excellence - Successful Stories from Clusters in Northern Europe. Cluster Excellence in the Nordic 
Countries, Germany and Poland. Project Report. VDI/VDE-IT. Retrieved from https://ufm.dk/en/publications/2011/files-2011/24-proofs-ofcluster-excellence_webedition.pdf

Paliokaite, A. (2019). An innovation policy framework for upgrading firm absorptive capacities in the context of catching-up economies. Journal of Entrepreneurship, Management and Innovation, 15(3), 103-130. https:// doi.org/10.7341/20191534

Parida, V., Westerberg, M., \& Frishammar, J. (2012). Inbound open innovation activities in high-tech SMEs: The impact on innovation performance. Journal of Small Business Management, 50(2), 283-309. https://doi. org/10.1111/j.1540-627X.2012.00354.x

Pichlak, M. (2012). Otwarte innowacje jako nowy paradygmat w zarządzaniu innowacjami. Zeszyty Naukowe: Organizacja i Zarzqdzanie/Politechnika Ślqska, 281-292. Retrieved from http://yadda.icm.edu.pl/yadda/ element/bwmeta1.element.baztech-article-BSL9-0066-0028

Piotrowski, M. (2014). Standardy Zarządzania Klastrem. Warszawa: Polska Agencja Rozwoju Przedsiębiorczości. Retrieved from https://www.parp. gov.pl/storage/publications/pdf/2016_standardy_klastrowe_iied.pdf

Polish Agency for Enterprise Development. (2012). Cluster Benchmarking in Poland. Retrieved from https://www.parp.gov.pl/storage/publications/ pdf/2012_cluster_benchmarking_en.pdf

Polish Agency for Enterprise Development. (2014). Cluster Benchmarking in Poland. Retrieved from https://www.parp.gov.pl/storage/publications/ pdf/2014_cluster_benchmarking_en.pdf

Porter, M. E. (1990). The competitive advantage of nations. Harvard Business Review, 68(2), 73-93.

Porter, M. E. (1998). Clusters and the new economics of competition. Harvard Business Review, 76(6), 77-90.

Radziwon, A., Bogers, M., \& Bilberg, A. (2014). Managing open innovation across SMEs: The case of a regional ecosystem. Academy of Management Proceedings, 2014(1). https://doi.org/10.5465/ ambpp.2014.11740abstract

Sieg, J. H., Wallin, M. W., \& Von Krogh, G. (2010). Managerial challenges in open innovation: A study of innovation intermediation in the chemical industry. R\&D Management, 4O(3), 281-291. https://doi.org/10.1111/ j.1467-9310.2010.00596.x

Sisodiya, S. R., Johnson, J. L., \& Grégoire, Y. (2013). Inbound open innovation for enhanced performance: Enablers and opportunities. Industrial Marketing Management, 42(5), 836-849. https://doi.org/10.1016/j. indmarman.2013.02.018

Smedlund, A. (2006). The roles of intermediaries in a regional knowledge system. Journal of Intellectual Capital. 7(2), 204-220. https://doi. org/10.1108/14691930610661863

Solvell, O., Lindqvist, G., \& Ketels, C. (2003). The Cluster Initiative Greenbook. Stockholm: Ivory Tower. http://www.cluster-research.org/greenbook.htm 
Sopińska, A., \& Mierzejewska, W. (2016). Otwarte innowacje źródłem sukcesu przedsiębiorstw. Zarzqdzanie i Finanse, 14(2), 259-374

Stanisławski, R. (2014). Open innovation wśród małych i średnich przedsiębiorstw jako instrument kształtowania przewagi konkurencyjnej. Ekonomia i Zarzqdzanie, 6(2), 169-184. https://doi.org/10.12846/j.em.2014.02.13

Stanisławski, R. (2017). Open Innovation a Rozwój Innowacyjny Mikro, Małych i Średnich Przedsiębiorstw. Łódź: Wydawnictwo Politechniki Łódzkiej.

Stanko, M. A., \& Henard, D. H. (2017). Toward a better understanding of crowdfunding, openness and the consequences for innovation. Research Policy, 46(4), 784-798. https://doi.org/10.1016/j.respol.2017.02.003

Taylor, S. J., Bogdan, R., \& DeVault, M. (2015). Introduction to qualitative research methods: $A$ guidebook and resource. John Wiley \& Sons.

Teece, D. J. (2014). The foundations of enterprise performance: Dynamic and ordinary capabilities in an (economic) theory of firms. Academy of Management Perspectives, 28(4), 328-352. https://doi.org/10.5465/ amp.2013.0116

Teirlinck, P., \& Spithoven, A. (2013). Formal R\&D management and strategic decision making in small firms in knowledge-intensive business services. R\&D Management, 43(1), 37-51. https://doi.org/10.1111/j.14679310.2012.00701.x

Tjong Tjin Tai, S. Y., Veraart, F., \& Davids, M. (2015). How the Netherlands became a bicycle nation: Users, firms and intermediaries, 1860-1940. Business History, 57(2), 257-289. https://doi.org/10.1080/00076791.2014.928695

Van de Vrande, V., De Jong, J. P., Vanhaverbeke, W., \& De Rochemont, M. (2009). Open innovation in SMEs: Trends, motives and management challenges. Technovation, 29(6-7), 423-437. https://doi.org/10.1016/j. technovation.2008.10.001

Veeckman, C., Schuurman, D., Leminen, S., \& Westerlund, M. (2013). Linking living lab characteristics and their outcomes: Towards a conceptual framework. Technology Innovation Management Review, 3(12), 6-15. https:// doi.org/ 10.22215/timreview/748

Wallin, M. W., \& Von Krogh, G. (2010). Organizing for open innovation: focus on the integration of knowledge. Organizational Dynamics, 39(2), 145154. https://doi.org/10.1016/j.orgdyn.2010.01.010

West, J., \& Bogers, M. (2014). Leveraging external sources of innovation: a review of research on open innovation. Journal of Product Innovation Management, 31(4), 814-831. https://doi.org/10.1111/jpim.12125

Zimmermann, J. B. (2001). The firm/territory relationships in the globalisation: Towards a new rationale. European Journal of Economic and Social Systems, 15(1), 57-75. https://doi.org/10.1051/ejess:2001108 


\begin{abstract}
Abstrakt
Otwarte innowacje to koncepcja, której cechy można postrzegać jako naturalnie łqczq̨ce się z opartq na bliskości charakterystykq klastrów. Celem tego artykułu było zbadanie potencjalnej roli klastrów jako pośredników otwartych innowacji dla swoich członków. Przeprowadzono przegląd literatury i badanie eksploracyjne, w tym pogłębione wywiady z ekspertami $w$ dziedzinach innowacji i klastrów w Polsce. W artykule dokonano połqczenia koncepcji otwartych innowacji i klastrów, zaproponowano i skategoryzowano role klastrów jako pośredników otwartych innowacji, a także wskazano czynniki, które moga mieć wpływ na pomyślne przyjęcie tej roli. Ponadto wykazano, że klastry mogq nie tylko zarzqdzać i pośredniczyć w kontaktach wewnq̨trz sieci członków, ale także kształtować i współtworzyć szerszy otwarty ekosystem innowacji. Wyniki badania przyczyniajq się do kompleksowego zrozumienia potencjalnych ról pośredników otwartych innowacji w odniesieniu do klastrów w kontekście kraju w trakcie transformacji gospodarczej. Ponieważ klastry odgrywajq rolę pośrednika otwartych innowacji, wsparcie publiczne tej roli może zwiększyć otwartość na współpracę nie tylko firm członkowskich, ale wszystkich uczestników regionalnego ekosystemu innowacji.
\end{abstract}

Słowa kluczowe: klastry, inicjatywy klastrowe, otwarte innowacje, ekosystem innowacyjny, pośrednik innowacyjny, pośrednik otwartych innowacji, polityka innowacji

\title{
Biographical note
}

Marita McPhillips is an Assistant Professor at Gdansk University of Technology (Poland), Faculty of Management and Economics. Dr. McPhillips has been involved in cluster development in Polish industry since 2005. Her main areas of research are: open innovation, inter-organizational networks, and innovation policies. Contact: marita.mcphillips@pg.edu.pl

\section{Conflicts of interest}

The author declares no conflict of interest.

\section{Citation (APA Style)}

McPhillips, M., (2020). Innovation by proxy-clusters as ecosystems facilitating open innovation. Journal of Entrepreneurship, Management and Innovation, 16(3), 101-128. https://doi.org/10.7341/20201634 